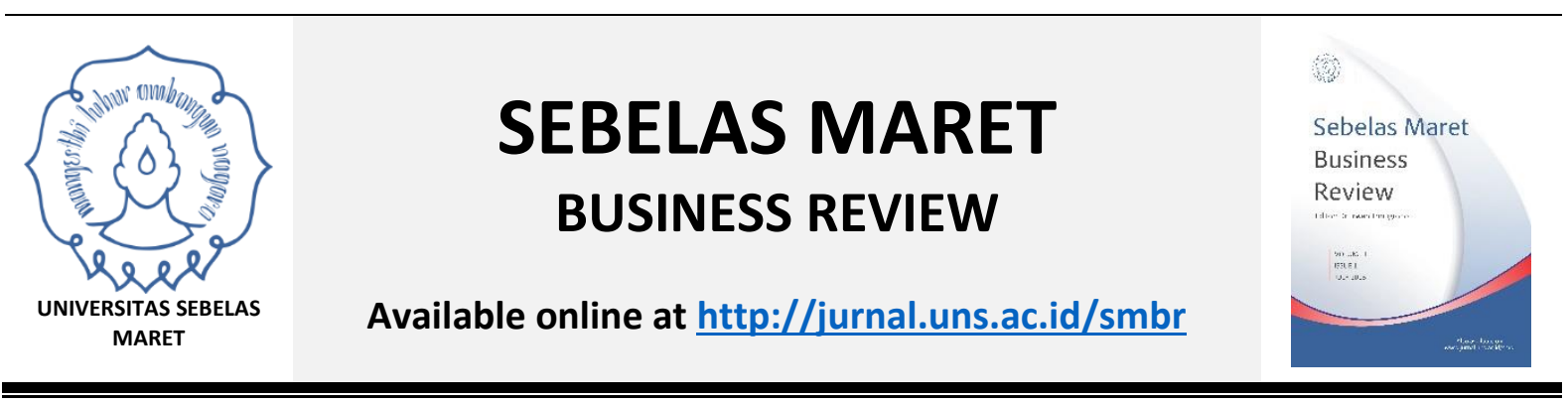

\title{
The Effect of Health Service Quality and Brand Image on Patients Loyalty, With Patients Satisfaction as Mediating Variable (A Study in Vip Ward Of Prof. Dr R Soeharso Ortopedics Hospital In Surakarta)
}

\author{
Tangkas Sibarani and Asri Laksmi Riani ${ }^{*}$
}

Master of Management, Faculty of Economics and Business, Universitas Sebelas Maret

*Email: asrilaksmiriani@yahoo.com

\begin{tabular}{|c|c|}
\hline ARTICLE INFO & ABSTRACT \\
\hline $\begin{array}{l}\text { Received } 23 \text { July } 2017 \\
\text { Received in Revised } \\
\text { Form } \\
\text { Accepted } 16 \text { September } \\
2017 \\
\text { Available online } 17 \\
\text { September } 2017\end{array}$ & $\begin{array}{l}\text { Business in healthcare service, like other service business, } \\
\text { should provide a service to its patients in order to maintain } \\
\text { patients' loyalty to be a loyal customer. A method in } \\
\text { increasing patients' satisfaction and loyalty is by focusing a } \\
\text { hospital's business on service quality aspect. Customers' } \\
\text { satisfaction is an effective measurement in assessing } \\
\text { service quality that is based on patient's consideration on } \\
\text { the service provided and their personal experience. The } \\
\text { main objective of this research is to understand the effect } \\
\text { of service quality and brand image on patients' loyalty, with } \\
\text { patients' satisfaction as mediating variable. To determine } \\
\text { the determinant of patients' satisfaction, the study is } \\
\text { focused on the inpatients, especially those who stay at VIP } \\
\text { ward, of Prof Dr R Soeharso Ortopedics Hospital Surakarta, } \\
\text { Central Java, Indonesia. The research method used is } \\
\text { survey, which is conducted by distributing a questionnaire } \\
\text { directly to the surveyed patients. Reliability and validity } \\
\text { test (using Servqual instrument) is conducted. The } \\
\text { respondents of this research consist of } 211 \text { inpatients. The } \\
\text { data collected is analyzed using SEM method. The result } \\
\text { shows that service quality affects patients' satisfaction } \\
\text { through brand image and service quality. Simultaneously, } \\
\text { service quality and brand quality affect patients' }\end{array}$ \\
\hline
\end{tabular}


satisfaction. Therefore, patients' satisfaction affects patients' loyalty. The implication of this research is the manager of a health care company should continuously improve the service quality and brand image, thus increasing patients' satisfaction, which will lead to patients' loyalty.

\section{BACKGROUND}

Nowadays, each company should face a tight competition, therefore they have to provide distinct service continuously. Most of service providers are often considering their customer in the product development process, thus establish a good customer relation. If a service provider can establish a relationship that can impress its customers, the relationship can lasts for a long term period (Gronroos, 2007). According to Sanchez, one of the objectives of marketing is to determine the customer's values and incorporating those values into marketing programs in order to increasing customer's loyalty (Sanchez, 2003). A good relationship between customer and service provider will leads to satisfied customer (Anderson \& Zimmerman, 1993). Based on the previous research, Salgaonkar states that satisfaction on the core service is important for the whole customer satisfaction, which in turn will affect customer loyalty. This also applies to healthcare services (Salgaonkar, 2006).

Healthcare service is a personal service. Generally the patients that visit a hospital or clinic are accompanied by their family or relatives, and usually have a certain level of physical stress or emotion. Therefore, the issues related with the capability in fulfilling patients expectation should be considered in the decision making by healthcare service provider (Baird, 2000).

Healthcare service is a unique and cannot be held on the same standards as consumer services applied to other industries. Customer decision on other healthcare service can be delayed or postponed, depends on the individuals need. On the other hand, this condition does not apply to health service, because delaying or postponing the decision to get health service could affects patient's health condition, which could aggravate patient's condition or even leads to death. Therefore, the determinants of patients' loyalty will be varied based on the factors related with loyalty and other aspects (Salgaonkar, 2006).

Each contact between consumer and an aspect of service system provide a chance to evaluate the service provider and the quality of service provided, to form an opinion, and to interact with other patients (Salgaonkar, 2006). By studying patients loyalty, which resulting from direct relationship marketing or patients' satisfaction, is important for the management of healthcare service in order to support their company in a long term.

The objective of this research is to analyze the method used by research subject in developing its customer loyalty on health service through customer satisfaction. This paper is divided into three parts. First, patients' loyalty on healthcare service that is based on the data obtained will be discussed. Second, the data will be analyzed based on respondents' gender. Third, patients' loyalty will be discussed by referring to respondents' age. Customers' satisfaction is a general attitude that is based on 
customer's experience after buying a product or service, which is manifested through affective reaction in its relation with the difference between customer's expectation with the reality ( Lai \& Chen,2011: Liu, Guo, \& Lee, 2011).

The result of previous researches on the effect of service quality on customers' satisfaction show that a high service quality will lead to higher satisfaction (Cronin et al., 2000; Bardy \& Cronin, 2001; Lai, Griffin, \& Babin, 2009). The effect of service quality on patients' satisfaction in healthcare service is discussed in several previous studies. A study conducted by Badri, Attia, and Ustadi (2009) in the UAE and Yesilada and Direktor (2010) in Cyprus shows that there is a positive effect of service quality on patients' satisfaction.

\section{OBJECTIVE}

The objectives of this research are:

1. To examine and analyze the effect of service quality on patients satisfaction.

2. To examines and analyze the effect of hospital image on patients' satisfaction.

3. To examines and analyze the effect of service quality on patients' loyalty.

4. To examines and analyze the effect of hospital image on patients' loyalty.

5. To examines and analyze the effect of patients' satisfaction on patients' loyalty.

6. To examines and analyze the effect of service quality on patients' loyalty with patients' satisfaction as mediating variable.

7. To examines and analyze the effect of hospital image on patients' loyalty with patients' satisfaction as mediating variable.

\section{LITERATURE REVIEW}

\section{Service Quality}

The dimension of service quality is divided into five SERVQUAL dimension by Parasuraman:

a. Tangibles (physical evidence) that is a company capability in showing its existence to external parties. Berry and Clark (1991) state that physical appearance affects customer's assessment on quality. Bitner (1990) states that physical appearance can affect customer's satisfaction.

b. Reliability is companies' capability to deliver the promised services accurately and reliably. Garvin (1987) finds that reliability tend to be reviewed in service quality evaluation. Parasuraman, et al., (1988) shows that reliability, in general, is the most important attributes that is sought after by customers in assessing service quality.

c. Responsiveness Bahia and Nantel (2000) does not ignoring responsiveness in their research and states that even with lack of reliability, SERVQUAL and all of its dimensions is well known and universally accepted as a measurement for perceived quality.

d. Assurance (guarantee and certainty) is knowledge, politeness, and employees' capability in fostering customer's trust to the company. Parasuraman, et al., (1991) including actions by employees such as polite behavior, trust, and understanding as a key element of assurance.

e. Empathy refer to the act in providing a sincere attention that is personal and individual to the customers, which aims to understand their needs. Empathy 
is used to replace access, communication, and customers' knowledge in the 10 basic dimensions to evaluate service quality (Zeithaml, et al., 1988).

\section{Brand image/hospital image}

Brand equity is a positive effect of differentiation that can be viewed from customers' response on a product or service. Brand equity is a brand power that can increase or decrease the brand value, this can be viewed form customers' response on a product or service (Kotler, 2003).

Positive image of a brand will encourage customer to choose a product over other products, which is a signal for the producer to be considered in the future. Meanwhile, excellent brand image will support companies' activities, especially in marketing.

\section{Patients' satisfaction}

The factors that affect customers' perception and expectation while doing a purchase is their needs and wants when purchasing a product or service, past experience on consuming certain goods or service, and other's people experience in consuming the goods or service that is delivered through advertisement.

\section{Patients' loyalty}

Customers loyalty in the service marketing context is defined by Dick \& Basu (1994) as a response that is highly related with a vow or promise to uphold commitment on the underlying a relationship continuity, and is usually reflected in continuous re-purchase from the same service provider, in a dedication basis and pragmatic limit. Loyal customer will do a re-purchase that is supported with positive opinion

\section{HYPOTHESIS DEVELOPMENT}

\section{The Effect of Service Quality on Patients Satisfaction}

Healthcare service quality has a close relation with patients' satisfaction, because quality encourage patients to build a stronger ties with the healthcare service provider and overall patients satisfaction will increase the number of implementation (provider). Therefore the first hypothesis is formulated as follow:

$\mathrm{H}_{1}$ : Service quality has a positive effect on patients' satisfaction.

\section{The Effect of Hospital Image on Customers Satisfaction}

The result of a research conducted by Sumaedi (2014) shows that brand image has a direct effect on customers' satisfaction on certain product. This result is supported by $\mathrm{Wu}$ (2011) who states that the market is changing rapidly. Therefore, the second hypothesis is formulated as follow:

$\mathrm{H}_{2}$ : Hospital image has a positive effect on patients' satisfaction.

\section{The Effect of Service Quality on Patients Loyalty}

Excellent service quality contributes to retention and customers' loyalty (Potluri and Zeleke, 2009). In term of healthcare service, Boshoff and Gray in the research of $\mathrm{Wu}$ (2011) proves that there is a positive effect of service quality on loyalty, which is measured through buying intention. Therefore, the third hypothesis is formulated as follow:

$\mathrm{H}_{3}$ : Service quality has a positive effect on patients' loyalty

\section{The Effect of Hospital Image on Patients Loyalty}

Merrilees and Fry (2002) find that brand image has a direct effect on loyalty. Davies and Chun in a research by Wu (2011) find that brand image has a direct 
effect on loyalty through customers' satisfaction. Therefore, the fourth hypothesis is formulated as follows:

$\mathrm{H}_{4}$ : Hospital image has a positive effect on patient loyalty

5. The Effect of Patients Satisfaction on Patients Loyalty

Cronin \& Taylor (1992), Dick \& Basu (1994), and Oliver (1997) state that customers' satisfaction is one of several factors that form customers' loyalty. McDougall and Levesque (2000) find that customer satisfaction is highly related with the creation of loyalty. Therefore, the fifth hypothesis is formulated as follow:

$\mathrm{H}_{5}$ : Patients satisfaction has a positive effect on patients' loyalty

6. Patients Satisfaction mediates the effect of Service Quality on Patients Loyalty

A research conducted by Stank et al in Bloemer and Kasper (1995) shows that customers' satisfaction mediates the effect of service quality on customers' loyalty. Therefore, the sixth hypothesis is formulated as follow:

$\mathrm{H}_{6}$ : Customer satisfaction mediates the effect of service quality on patients' loyalty

7. Customer satisfaction mediates the Effect of Hospital Image on Patients' Loyalty

Positive hospital brand image usually leads to high patients' satisfaction in the hospital, and satisfied customer tends to have higher potential to be a loyal customer. The result of a research by Sondoh Jr et al., (2007) shows that customers' satisfaction mediates the effect of brand image on customer loyalty. Therefore the seventh hypothesis proposed is:

H7: Patients satisfaction mediates the effect of hospital image on patients' loyalty.

\section{RESEARCH MODEL}

Based on the hypotheses proposed, the correlation of each variables is presented in a research model in Figure II. 1.

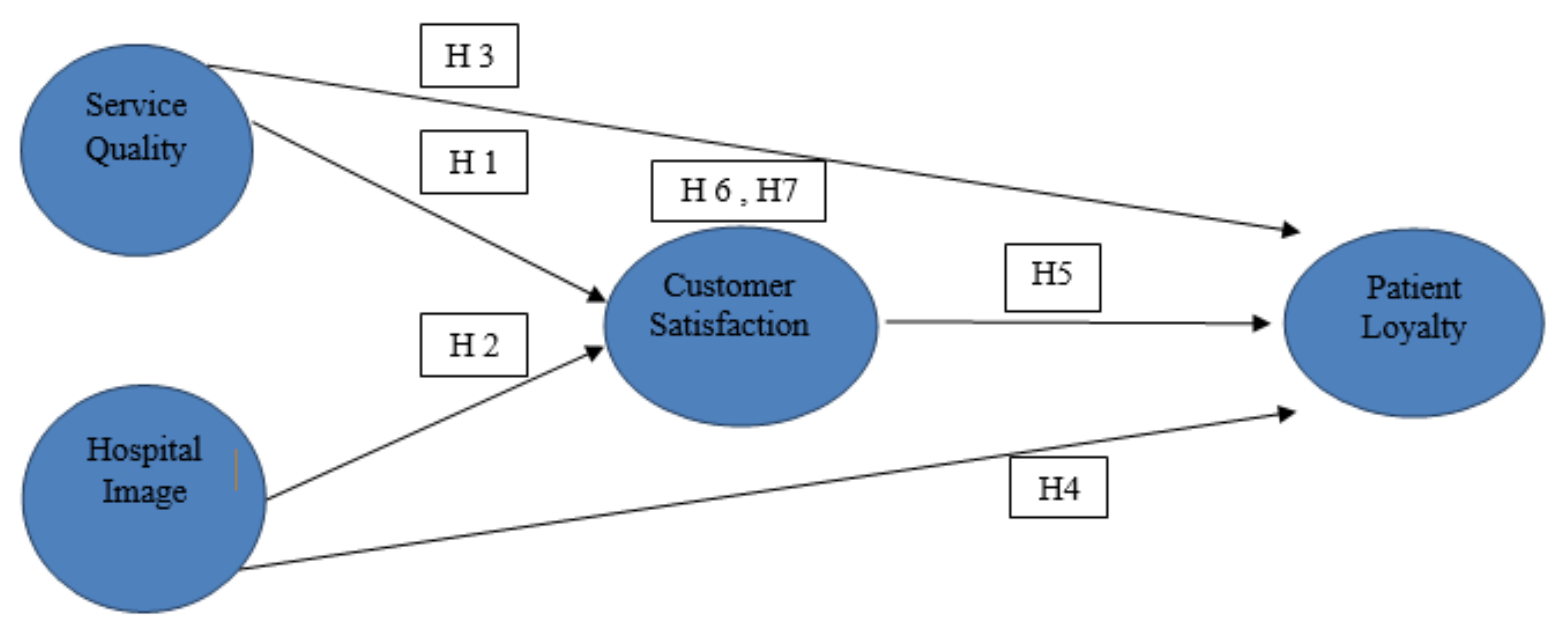

Figure II.1

Research Model 


\section{RESEARCH METHOD}

\section{Research Design}

This research is categorized as a hypothesis test research. Viewed from the correlation of each variable, this research can be categorized as causal research, which is a research that shows the direction of the correlation between independent variables and dependent variables (Jogiyanto, 2010). The unit analysis of this research is individual, which mean the data analyzed is collected from individual inpatients who are currently under treatment in VIP ward in RSO Prof Dr R Soeharso Surakarta.

\section{Population, Sample, and Sampling Technique}

The population of this research is all patients who had been or being treated in VIP ward of RSO Prof Dr R Soeharso Surakarta. The sampling technique used in this research is non probability sampling. The respondents are chosen using convenience sampling method, which is sampling technique that based on convenience (Sekaran \& Bougie, 2009).

The analysis will be conducted using structural equation modelling (SEM) technique, thus the minimal amount of sample size for all of constructs are 150 respondents (Hair et al., 2010). In order to anticipate the lack of sample size due to broken questionnaires, thus we distribute 250 questionnaires.

\section{Operationalization and Variable Measurement}

a. Service quality

Service quality is measured using SERVQUAL scale (Parasuraman et al., 1988) that is adjusted for healthcare service and modified by Alrubaiee and Alkaa'ida (2011). The questionaire that consist of 28 questions item to measure the quality of healthcare service, is given to the respondents to assess the quality of service they get. Each item is measured using Likert scale with 5 alternative options namely, strongly disagree (Sangat Tidak Setuju - STS), Disagree (TS), Neutral (N), Agree (S), and Strongly Agree (SS).

b. Hospital image

Hospital image is measured using 5 main dimensions namely, brand identity, brand personality, brand association, brand attitude \& behavior, and brand benefit \& competence. This construct is represented by 17 questions item in the questionnaire.

c. Patients satisfaction

Patients satisfaction is defined as the level of customer expectations and needs are quite fulfilled by the service provider. This variable is measured using 5 item question in the questionnaire.

d. Patients loyalty

Patients' loyalty is defined as in-depth commitment to do a repurchase and resubscribe a product consistently in the future, thus led to continuous purchasing of the same brand (Oliver, 1999).

\section{Data Source and Data Collection Method}

The data used in this research is primary data. Primary data is a type of data that is collected and processed directly by an organization or individuals, with a specific objective (Sekaran \& Bougie, 2009).

Data collection method in this research is personally administrated questionnaires method, in which the researcher delivers the questionnaire directly to respondents (Sekaran \& Bougie, 2009). 


\section{Data analysis method}

a. Descriptive Analysis

b. Instrument Test

1). Validity Test using confirmatory factor analysis (CFA). Question item is considered as valid if it has a factor loading $\geq 0.50$ (Ferdinand, 2005).

2). Reliability Test

The accepted rate of reliability test value is $\geq 0.70$.

c. Hypothesis Test

To test the hypothesis, this research uses Structural Equation Modeling (SEM). Several aspects that should be considered in conducting this test are model assumption, conformity analysis, and path coefficient analysis that can be conducted in the following step:

1. Model Assumption

1) Data Normality

2) Outlier Evaluation

3) Has a positive degree of freedom $(d f)$

4) The level of minimum probability value is 0.1 or 0.2 , however, the probability value of 0.05 is acceptable (Hair et al., 2010).

5) Calculate chi-square $\left(\chi^{2}\right)$ (Hair et al.; Hulland et al. in Ferdinand, 2005).

6) CMIND/DF

2. Test the model conformity using several additional index, such as: Goodness of Fit Index (GFI), Adjusted Goodness of Fit Index (AGFI), Tucker-Lewis Index (TLI), Comparative Fit Index (CFI), and Root Mean Square Error of Approximation (RMSEA).

3. Path Coefficient Analysis

This analysis is based on the significance of regression weight model. The criterion for a path to be significant is, it should have C.R. value $\geq t$ table value, or significance level (p) is lower than 5\% (Ferdinand, 2005).

\section{DATA ANALYSIS AND DISCUSSION}

\section{Descriptive Analysis}

a. Respondent Characteristics

Table IV.1 shows that most of the respondents are between 15 to 24 years old, are male, married, and most of them hold undergraduate degree (122 respondents). 
Table IV.1

Respondents Characteristic Description

\begin{tabular}{|c|c|c|}
\hline Characteristic & Frequency & $\begin{array}{c}\text { Percentage } \\
\text { (\%) }\end{array}$ \\
\hline \multicolumn{3}{|c|}{ Age } \\
\hline $15-24$ years old & 69 & 32.7 \\
\hline $25-34$ years old & 58 & 27.5 \\
\hline $35-44$ years old & 51 & 24.2 \\
\hline $45-54$ years old & 25 & 11.8 \\
\hline $55-64$ years old & 7 & 3.3 \\
\hline $65-74$ years old & 1 & 0.5 \\
\hline \multicolumn{3}{|c|}{ Gender } \\
\hline Male & 127 & 60.2 \\
\hline Female & 84 & 39.8 \\
\hline \multicolumn{3}{|c|}{ Marriage Status } \\
\hline Married & 158 & 74.9 \\
\hline Single & 53 & 25.1 \\
\hline \multicolumn{3}{|c|}{ Education } \\
\hline SMP/Equal & 5 & 2.4 \\
\hline SMU/Equal & 48 & 22.7 \\
\hline Diploma & 27 & 12.8 \\
\hline $\begin{array}{l}\text { S1 } \\
\text { (Undergraduate) }\end{array}$ & 122 & 57.8 \\
\hline S2 (Master) & 9 & 4.3 \\
\hline \multicolumn{3}{|c|}{ Occupation } \\
\hline $\begin{array}{l}\text { PNS (Civil } \\
\text { Servant) }\end{array}$ & 26 & 12.3 \\
\hline Private Workers & 123 & 58.3 \\
\hline Housewife & 28 & 13.3 \\
\hline Unemployed & 8 & 3.8 \\
\hline Farmer & 2 & 0.9 \\
\hline Students & 24 & 11.4 \\
\hline
\end{tabular}

Source: Processed Data, 2017

\section{RESEARCH INSTRUMENT TEST}

\section{Validity Test}

The result of CFA test for each service quality item statement, which consists of five dimensions that are tangible, reliability, responsiveness, assurance, and empathy, shows that only 23 items out of 28 items are valid. The items statements on hospital image, which consist of five dimensions that are brand identity, brand personality, brand association, brand attitude \& behavior, and brand benefit \& competence, with total 17 statements show that all items are valid. Patients' satisfaction with 5 statements and patients' loyalty with 4 statements are valid. 


\section{Reliability Test}

After the validity test, the next step is reliability test. This test aims to know the consistency of questions. The result of reliability test for each variable is presented in Table IV. 7.

Table IV.7

Reliability Test Result

\begin{tabular}{|l|l|}
\hline \multicolumn{1}{|c|}{ Variable } & Construct Reliability \\
\hline Service quality: & \\
\hline - Tangible (T) & 0.924 \\
\hline - Reliability (R) & 0.906 \\
\hline - Responsiveness (RS) & 0.925 \\
\hline - Assurance (A) & 0.903 \\
\hline - Empathy (EM) & 0.904 \\
\hline Hospital image: & 0.911 \\
\hline - Brand Identity (BI) & 0.870 \\
\hline - Brand Personality (BP) & 0.897 \\
\hline - Brand Association (BA) & 0.818 \\
\hline - Brand Attitude \& Behavior & \\
\hline (BAT) & 0.892 \\
\hline Brand Benefit \& Competence & 0.917 \\
\hline Patient satisfaction (KP) & 0.907 \\
\hline Patient loyalty (LP) & \\
\hline
\end{tabular}

Source: Processed Data, 2017

The minimum value for a variable to be considered reliable is based on the significance value at 0.7 . All variable is considered reliable.

\section{HYPOTHESIS TEST} used.

To test the hypothesis in this research, structural equation modeling (SEM) is

1. Model Assumption

\section{a. Data Normality}

The data in this research is normally distributed based on multivariate result, thus the analysis can be conducted.

\section{b. Outliers Evaluation}

Test on multivariate outliers is conducted using mahalanobis distance criteria at $\mathrm{p}$ level $<0.001$. If there are 49 indicators in this research, all cases that has Mahalanobis distance that is higher than $\chi^{2}(49 ; 0.001)=85.35$ is multivariate outlier.

\section{Goodness-of-Fit}

Table IV.10 present the result of goodness of fit of this research model. In this research the value of $\chi^{2}$ shows a significance value higher than 0.05 with $\chi^{2}$ value of 1189.166, which mean the model in this research is fit. In general, the model proposed shows an appropriate level of goodness of fit. 
Table IV.10

The Result of Model Goodness-of-Fit

\begin{tabular}{|l|l|l|l|}
\hline Goodness-of-fit Indices & Cut-off Value & Result & $\begin{array}{c}\text { Model } \\
\text { Evaluation }\end{array}$ \\
\hline Chi-Square $\left(\chi^{2}\right)$ & Expected to be & 1189.166 & Fit \\
Degrees of freedom & low & 1111 & Fit \\
Probability level $(p)$ & Positive & 0.051 & Fit \\
CMIN/DF & $\geq 0.05$ & 1.070 & Fit \\
GFI & $\leq 2.0$ & 0.820 & Marginal \\
AGFI & $\geq 0.90$ & 0.801 & Marginal \\
TLI & $\geq 0.90$ & 0.991 & Fit \\
CFI & $\geq 0.90$ & 0.991 & Fit \\
RMSEA & $\geq 0.90$ & 0.018 & Fit \\
& $\leq 0.08$ & & \\
\hline
\end{tabular}

Source: Processed data, 2017

\section{Path Coefficient Analysis}

Table IV.11

Regression Weights

\begin{tabular}{|c|c|c|c|c|c|c|}
\hline & & & Estimate & S.E. & C.R. & $P$ \\
\hline $\begin{array}{l}\text { Patients } \\
\text { Satisfaction }\end{array}$ & $<---$ & Service Quality & .663 & .082 & 8.076 & .000 \\
\hline $\begin{array}{l}\text { Patients } \\
\text { Satisfaction }\end{array}$ & $<---$ & Hospital Image & .333 & .073 & 4.561 & .000 \\
\hline Patients Loyalty & $<---$ & $\begin{array}{l}\text { Patients } \\
\text { Satisfaction }\end{array}$ & .345 & .089 & 3.859 & .000 \\
\hline Patients Loyalty & $<---$ & Service Quality & .639 & .099 & 6.419 & .000 \\
\hline Patients Loyalty & $<---$ & Hospital Image & .146 & .070 & 2.093 & .036 \\
\hline
\end{tabular}

Source: Processed data, 2017

The tests result presented in Table IV.11 show that, from the five paths analyzed, all paths have significant correlation. This can be viewed from its significance level (p) of hypothesis test that is lower than $5 \%$. The result of direct effect analysis, indirect effect, and total effect of a variable on other variable is presented in Table IV.12: 
Table IV.12

Direct Effect, Indirect Effect, and Total Effect

\begin{tabular}{|l|l|c|c|c|}
\hline \multicolumn{2}{|c|}{ Variable } & \multicolumn{3}{c|}{ Effect ( $\boldsymbol{\beta})$} \\
\hline \multicolumn{1}{|c|}{ Independent } & Dependent & Direct & Indirect & Total \\
\hline Service Quality & \multirow{2}{*}{$\begin{array}{l}\text { Patients } \\
\text { Hospital Image }\end{array}$} & 0.615 & - & 0.615 \\
\cline { 4 - 5 } & Satisfaction & 0.288 & - & 0.288 \\
\hline Service Quality & \multirow{3}{*}{$\begin{array}{l}\text { Patients } \\
\text { Hospital Image }\end{array}$} & 0.546 & 0.195 & 0.741 \\
\cline { 3 - 5 } $\begin{array}{l}\text { Patients } \\
\text { Satisfaction }\end{array}$ & Loyalty & 0.116 & 0.092 & 0.208 \\
\cline { 3 - 5 } & & & - & 0.318 \\
\hline
\end{tabular}

Source: Processed data, 2017

a. The effect of service quality on patients' satisfaction.

The calculation results presented in Table IV.11, show CR value of service quality on patients' satisfaction is 8.076 with significance value 0.000 , and thus hypothesis 1 is supported.

b. The Effect of hospital image on patients' satisfaction.

Table IV.11 shows CR value of hospital image on patients satisfaction is 4.561 with significance value of 0.000 , thus hypothesis 2 is supported.

c. The effect of service quality on patients' loyalty.

Based on Table IV.11, show CR value of service quality on patients loyalty is 6.419 with significance value of 0.000 , thus hypothesis 3 is supported.

d. The effect of hospital image on patients' loyalty.

Based on Table IV.11, show CR value of hospital image on patients loyalty is 2.093 with significance value of 0.036 , thus hypothesis 4 is supported.

e. The effect of patients' satisfaction on patients' loyalty.

Based on Table IV.11, show CR value of patients' satisfaction on patients loyalty is 3.859 with significance value of 0.000 , thus hypothesis 5 is supported.

4. Test on Mediation

Model 1 test the effect of service quality and hospital image on patients' loyalty without the mediation of patients' satisfaction. Model 2 test the effect of service quality and hospital image on patients' loyalty with patients' satisfaction as mediating variable. Moreover, to examine whether the direct effect and indirect effect of patients satisfaction mediates the effect of service quality and hospital image on patients loyalty is significant or not, sobel test is conducted. The explanation of each test is presented in Table IV.13 and Table IV.14. 
Table IV.13

Regression Weights for Mediating Effect

\begin{tabular}{|c|l|c|c|c|c|}
\hline Model & \multicolumn{1}{|c|}{$\begin{array}{c}\text { The Effect of } \\
\text { Variable }\end{array}$} & Estimate & SE & CR & Sig. (p) \\
\hline \multirow{2}{*}{ I } & $\begin{array}{l}\text { Service quality on } \\
\text { patients loyalty }\end{array}$ & 0.864 & 0.092 & 9.350 & 0.000 \\
\cline { 2 - 6 } & $\begin{array}{l}\text { Hospital image on } \\
\text { patients loyalty }\end{array}$ & 0.263 & 0.071 & 3.712 & 0.000 \\
\hline \multirow{2}{*}{ II } & $\begin{array}{l}\text { Service quality on } \\
\text { patients satisfaction }\end{array}$ & 0.663 & 0.082 & 8.076 & 0.000 \\
\cline { 2 - 6 } & $\begin{array}{l}\text { Hospital image on } \\
\text { patients satisfaction }\end{array}$ & 0.333 & 0.073 & 4.561 & 0.000 \\
$\begin{array}{l}\text { Service quality on } \\
\text { patients loyalty }\end{array}$ & $\begin{array}{l}\text { Hospital image on } \\
\text { patients loyalty }\end{array}$ & 0.639 & 0.099 & 6.419 & 0.000 \\
\cline { 2 - 6 } & $\begin{array}{l}\text { Patients satisfaction } \\
\text { on patients loyalty }\end{array}$ & 0.345 & 0.089 & 3.859 & 0.000 \\
\hline
\end{tabular}

Source: Processed data, 2017

Table IV.13 shows that all correlation that is tested in both model 1 and model 2 are significant at significance level of 0.05 .

Table IV.14

Sobel Test Result

\begin{tabular}{|l|c|c|}
\hline \multirow{2}{*}{ Effect } & \multicolumn{2}{|c|}{ Sobel Test Value } \\
\cline { 2 - 3 } & t & Sig (p) \\
\hline $\begin{array}{l}\text { Service quality on patients loyalty } \\
\text { with patients satisfaction as mediating } \\
\text { variable }\end{array}$ & 3.482 & 0.000 \\
\hline $\begin{array}{l}\text { Hospital image on patients loyalty } \\
\text { with patients satisfaction as mediating } \\
\text { variable }\end{array}$ & 2.946 & 0.003 \\
\hline
\end{tabular}

Source: Processed data, 2017

The sobel test results show that the indirect effect of service quality and hospital image on patients' loyalty through patients' satisfaction is significant. This mean that patients' satisfaction mediates the effect of service quality and hospital image on patients' loyalty.

a. The effect of service quality on patients loyalty with patients satisfaction as mediating variable

The result of sobel test presented in Table IV.14 shows that there is a significant indirect effect of service quality on patients loyalty, thus hypothesis 6 is supported. This shows that patients' satisfaction mediates the effect of service quality on patients' loyalty. The mediating effect of patients' loyalty in this research is a partial mediation. 
b. The effect of hospital image on patients loyalty with patients satisfaction as mediating variable

The result of sobel test presented in Table IV.14 also shows that the indirect effect of hospital image on patients loyalty is significant, thus it can be concluded that hypothesis 7 is supported. This means that patients' loyalty mediates the effect of hospital image on patients' loyalty.

\section{DISCUSSION}

The summary of the result of hypothesis test is presented in Table IV.15 and is discussed as follow.

\section{Table IV.15 \\ The Summary of Hypothesis Test Result}

\begin{tabular}{|l|c|}
\hline \multicolumn{1}{|c|}{ Hypothesis } & Result \\
\hline $\mathrm{H}_{1}$ : Service quality has an effect on patients satisfaction & Supported \\
\hline $\mathrm{H}_{2}:$ Hospital image has a positive effect on patients satisfaction & Supported \\
\hline $\mathrm{H}_{3}:$ Service quality has a positive effect on patients loyalty & Supported \\
\hline $\mathrm{H}_{4}:$ Hospital image has a positive effect on patients loyalty & Supported \\
\hline $\begin{array}{l}\mathrm{H}_{5}: \text { Patients satisfaction has a positive effect on patients } \\
\text { loyalty }\end{array}$ & Supported \\
\hline $\begin{array}{l}\mathrm{H}_{6}: \text { Patients satisfaction mediates the effect of service quality } \\
\text { on patients loyalty }\end{array}$ & Supported \\
\hline $\begin{array}{l}\text { H7: Patients satisfaction mediates the effect of hospital image } \\
\text { on patients loyalty }\end{array}$ & Supported \\
\hline
\end{tabular}

\section{The effect of service quality on patients satisfaction}

The result of path analysis presented in Table IV.11 shows that service quality has a positive effect on patients' satisfaction. This can be explained as a patient get an excellent service, which is viewed from the quality of the facilities, quick and precise service performed by the nurses and doctors, as well as a clear and simple administration service provided, will increase patients' satisfaction on the hospital. This result support the result of a research conducted by Shabbir et al., (2010); Naik et al., (2013); Kitapci et al., (2014); and Sathiyaseelan \& Gnanapala (2015) that find service quality affects customers' satisfaction.

\section{The effect of hospital image on patients satisfaction}

The result of path analysis presented in Table IV.11 shows that hospital image has a positive effect on patients satisfaction. Hospital image is the impression in customer's mind about a hospital. When a customer has a favorable impression on certain hospital, their satisfaction on the service provided by the hospital will increase. This result support the result of Lai et al., (2009); Hu \& Huang (2011); Hidajahningtyas et al., (2013); and Juhana et al., (2015) that shows companies' image has a positive effect on customers' satisfaction.

\section{The effect of service quality on patients loyalty}

The result of path analysis presented in Table IV.11 shows that service quality has a positive effect on patients' loyalty. This is because a patient is loyal to a hospital after they feel that the service provided by the hospital is excellent. Service quality will encourage a customer to do a re-purchase, purchase more, or purchase other service. It will make customers to be less sensitive on price and 
more willing to share information about their experience about the service with other people (Venetis and Ghauri, in Aydin and Ozer, 2005). This result support the result of research by Kumar et al., (2012) and Kesuma et al., (2013) who find that service quality has a positive effect on customers' loyalty.

4. The effect of hospital image on patients loyalty

The result of path analysis presented in Table IV.11 shows that hospital image has a positive effect on patients loyalty. This is because a patient will be loyal to a hospital if they view the hospital to have a good image. A company that has a good image in the customers' mind will attract the customer to use the same service provided by the same company, do re-purchase, and recommending the service to other people. This result support the result of research by $\mathrm{Wu}$ (2011) and Chung et al., (2015) who find that companies' image has a positive effect on customers' loyalty.

\section{The effect of patients satisfaction on patients loyalty}

The result of path analysis presented in Table IV.11 shows that patients' satisfaction has a positive effect on patients' loyalty. This is because patients whose expectation is fulfilled tend to do re-purchase and recommending the service provided by the hospital to other people. Satisfied customer tend to find it difficult to change their preference on a product. This result support the result of research by Lai et al., (2009); Wu (2011); Hidajahningtyas et al., (2013); and Juhana et al., (2015) who find that customers' satisfaction has positive effect on customers' loyalty.

6. The mediating role of patients satisfaction on the effect of service quality on patients loyalty

The result shows that customers' satisfaction mediates the effect of service quality on patients' loyalty. This is because a patient will be loyal to a hospital if they are satisfied with the service provided by the hospital. This result support the result of research by Caruana (2002) and Darsono (2008) who find that customers' satisfaction mediates the effect of service quality on customers' loyalty.

7. The mediating role of patients satisfaction on the effect of hospital image on patients loyalty

Patients' satisfaction will increase if they have a good impression on a hospital, thus they will be more willing to use the same service provided by the same hospital and recommend it to other people. This result support the result of the research by Sondoh Jr et al., (2007) who finds that customers' satisfaction meditates the effect of hospital image on customers' loyalty.

\section{CONCLUSIONS AND RECOMMENDATIONS}

\section{Conclusions}

Based on the analysis result using SEM, thus we can conclude that:
a. Service quality has a positive effect on patients' satisfaction.
b. Hospital image has a positive effect on patients' satisfaction.
c. Service quality has a positive effect on patients' loyalty.
d. Hospital image has a positive effect on patients' loyalty.
e. Patients' satisfaction has a positive effect on patients' loyalty.
f. Patients' satisfaction mediates the effect of service quality on patients' loyalty.
g. Patients' satisfaction mediates the effect of hospital image on patients' loyalty. 


\section{Limitations}

This research only uses service quality and image as the determinant of patients' satisfaction and loyalty. It is possible that there are other factors that affect patients' satisfaction and loyalty, such as perceived value.

\section{Recommendations}

Based on this research result, there are several factors that determine patients' satisfaction and loyalty that can be considered to determine which marketing strategy should be used. Therefore, based on the research, hospital management should build a favorable image in a long term basis using identification and efficient management in term of promise, positioning, personality, and people. The brand, in this case Orthopedics Hospital of Prof Dr R Soeharso in Surakarta, should be able to prove the promise they offered and understand their customer characteristic. Therefore, it can be a brand that close to their customers' characteristics. Moreover, hospital managers should do a continuous innovation on the facilities and services that is available, in order to anticipate the future needs and expectation of the customers.

\section{REFERENCES}

Abdelsalam Adam Hamid,Siddig Balal Ibrahim. 2015. Interaction effect of perceived service quality and brand image on costumer satisfaction. Asian Journal of Management Sciences, 03 (10), 1-8.

Abdel Fattah Mahmoud Al-Azzam. 2015. The Impact of Service Quality Dimensions on Customer Satisfaction: A Field Study of Arab Bank in Irbid City, Jordan. European Journal of Business and Management. Vol.7.No.15.

Aditya Wardana, Budi Rustandi Kartawinata, Syahputra. 2014. Analysis of the Effect of Service Quality, Customer Value, and Customers Satisfaction to Behavioral Intensions at Auto 2000 Car Service Stations in Indonesia. International Journal of Science and Research (IJSR).Vol 3 Issue 11.

Ahmadreza Hamid, Mahsa Salimi, Amineh Afshar Kermanshahi. 2015. The mediating Role of Patient Satisfaction in Respect to the Aspects of Perceived Service Qualities and Their Loyalty (Case study: Private Hospital in Mashhad).International Journal of Scientific management and Development. Vol.3 (12), 693-701.

Albert Caruana. Service loyalty. 2012. The Effects of Service Quality and the Mediating Role of Customer satisfaction. European journal of Marketing. Vol 36, No. 7/8, 2012, pp.811-828.

Ali Anbori, Sirajoon Noor Ghani, Hematram Yadav,Aqil Mohammad Daher, and Tin Tin Su. 2010. Patient Satisfaction and Loyalty to the Private Hospital in Sanaa, Yemen. International Journal for Quality in Healthcare vol.22 no 4.

Ali Ramadan Musbah, Nasser Habtoor. 2015. Testing the validity of a Proposed model for Measuring Customer Satisfaction in Libyan Banks Using Confirmatory Factor Analysis. International Journal of Science and Research (IJSR). Volume 4 Issue 11.

A.M. Iddrisu, I.K. Nooni, Fianko, K.S., W. Mensah. 2015. Assessing the Impact of Service Quality on Customer Loyalty: A Case Study of the Celluler Industry of Ghana. British Journal of Marketing Studies. Vol.3, No.6, pp. 15-30.

Christo Bisschoff, Hannes Clapton.2014. Measuring Customer service in a Private Hospital. Problems and Perspectives in Management, Volume 12, Issue 4. 
Christopher G Lis, Mark Rodeighier. 2011. Digant Gupta. The Relationship between Perceived Service Quality and Patient Willingness to Recommend at a National Oncology Hospital Network. BMC Health Services Research 2011, 11:46.

Daniel Asante Kyei., Dr Bedman Narteh. 2016. Relationship Marketing Practices and Customer Satisfaction in the Ghanaian banking Sector. European Journal of Business and Management. Vol.8, No.16,

Dudung Juhana, Ester Manik, Catleya Febrinella and Iwan Sidharta. 2015. Empirical Study on Patient Satisfaction and Patient Loyalty on Public Hospital in Bandung Indonesia. IJABER, Vol. 13, No. 6 (2015): 4305-4326.

Dwi Aryani, Febrina Rosinta. 2010. Pengaruh Kualitas Layanan terhadap Kepuasan pelanggan dalam membentuk Loyalitas Pelanggan. Bisnis \& Birokrasi, Jurnal Ilmu Administrasi dan Organisai. Vol 17, Nomor 2.

Ehsan Zarei, Abbas Daneshkohan, Behrouz Pouragha, Sima marzban \& Mohammad Arab. 2015. An Empirical Study of the Impact of Service Quality on Patient satisfaction in Private Hospitals, Iran. Global Journal of Health Science and Education. Vol. 7, No. 1

Dr Galib Mohammed Al. Bostanji. 2013. The Impact of Service Quality on Customerrs Loyalty. A Study on Five Star Hotel's Customers in Ryadh, KSA. European Journal of Business and Management. Vol.5, No. 31.

Hallouz Wafaa, Benhabib Abderrezzak. 2014. A study of the Relationship between banking Service Quality and Customer Satisfaction in Algerian Public banks. International Journal of Science and Reserach (ISJR). Vol.3 Issue 1.

Hayat Belaid, Ahmed Bouchenafa, Abd Elkader barich, Karima Maazouzi. 2015. The Quality of Health Services in Bechar Public Hospital Institution. International Journal of Social Sciences. Vo. IV, No. 2.

Herni Justiana Astuti, Keisuke Nagase. 2014. Patient loyalty to Healthcare Organizations; Relationship marketing and satisfaction. International Journal of Management and Marketing Research. Vol. 7, No. 2, , pp 39 - 56.

Ida Ayu Werdiningsih Kesuma, Djumilah Hadiwidjojo, Ni Luh Putu Wiagustini 7 Fatchur Rohman. 2013. Service Quality Influence on Patient Loyalty: Customer Relationship Management as Mediation Variable (Study on Private Hospital Industry in Denpasar). International Journal of Business and Commerce. Vol. 2, No. 12: 01-14.

J.Rama Krishna Naik, Dr Byram Anand, Irfan Bashir.2013. Healthcare Service Quality and word of mouth: Key drivers to achieve Patient Satisfaction. Pacific Business Review International. Volume 5 Issue 12.

Kai Chieh $\mathrm{Hu}$ and Mei Chieh Huang. 2011. Effects of Service Quality, Innovation and Corporate Image on Customers Satisfaction and Loyalty of Air Cargo Terminal. International Journal of Operations Research. Vol8 No. 4, 36-47.

Ki-Han Chung, Ji-Eun Yu, Won-Jong Kim, Jae-Ik Shin. 2015. The Effect of Perceived Value on Customer loyalty in a Low-Priced Cosmetic Brand of South Korea: The moderating Effect of Gender. Advanced Science and Technology Letters. Vol.114 (Business), pp. 40-44.

Kofi Poku, Mariama Zakari, Ajara Soali. 2013. Impact of Service Qualitry on Customer Loyalty in the Hotel Industry: An Empirical Stdy from Ghana. International Review of Management and Business Research. Vol. 2. Issue .2.

Leila Rahmani-Nejad, Zahra Firoozbakht, Amin Taghipoor. 2014. Service Quality, Relationship Quality and Customer Loyalty (Case Study: Banking Industry in Iran).Open Journal of Social Sciences, 2, 262-268. 
Licen Indahwati Darsono. 2008. Hubungan Perceived Service Quality dan Loyalitas : Peran Trust dan Satisfaction Sebagai Mediator. The 2nd National Conference UKWMS, Surabaya.

Lo Liang Kheng, Osman Mahamad, T Ramayah, Rahim Mosahab. 2010. The Impact of Service Quality on Customer Loyalty: A Study of Banks in Penang, Malaysia. International Journal of Marketing Studies. Vol. 2. No. 2.

Margaret Njoki Maina. 2016. Effect of Customer Perfection on Performance of Private Hospital in Nairobi: A Case Study of Karen Hospital. International Journal of Business anf Commerce. Vol. 4, No.05: (60-71)

Marzouq A Alqeed. 2013. Service Quality Relationship with Customer Satisfaction and Business Profitability (A Case Study of Royal Jordanian). European Journal of Business and Management. Vol. 5, No. 1.

Monal Deshmukh, Girish Chourasia. 2012. The Impact of Perceived Service Quality on Customer Loyalty in IT Sector of India. International Journal of Science and Research (IJSR). Vol. 1 Issue 2.

Muhammad Saloma Emang, Gladys Sebi Entigar, Noor Haty Nor Azam, Pauline Achan, jati Kesuma, jastu. 2015. A Study of Patients satisfaction on Service Quality in the Sarawak Rural Health Care Industry. Research Journal of Social Sciences; 8(7): pages 103-110.

Neringa Ivanauskiene, Justina Volungenaite. 2014. Relations between Service Quality and Customer Loyalty: An Empirical Investigation of Retail Chain Stores in Emerging Markets. American International Journal of Social Science. Vol. 3, No 2.

Nurullah Hidajahningtyas, Andi Sularso, Imam Suroso. 2013. Pengaruh Citra,Kualitas layanan dan Kepuasan terhadap Loyalitas Pasien di Poliklinik Eksekutif Rumah Sakit daerah dr Soebandi Kabupaten Jember.JEAM Vol XII No. 1

Paul Mensah Agyei, James M Kilika. 2013. The Relationship between Service Quality and Customer Loyalty in the Kenyan Mobile Telecommunication Service Industry. European Journal of Business and Management, Vol. 5, No. 23.

Ping Lei and Alain Jolibert. 2012. A three-model comparison of the Relationship between Quality, Satisfaction and Loyalty: an Empirical Study of the Chinese Healthcare System. BMC Health Services Research 12:436

Praveen Shrivastava. 2016. House of Quality: An Effective Approach to Achieve Customer satisfaction \& Business Growth in Industries. International Journal of Science and Research. Vol. 5 Issue 9.

Rupa Rathee, Pallavi Rajain. 2015. Assesment of Service Quality in Public banks of NCR. International Journal of Science and Research (IJSR). Vol. 4 Issue 4.

Shahbaz Shabbir,Hans Ruediger Kaufmann and Mudassar Shahzad. 2010. Service quality,word of mouth and trust :Drivers to achieve patients satisfaction. Scientific research and essays Vol.5 (17), pp.2457-2462.

Sugiyono Prof.,Dr. 2014. Metode Penelitian Manajemen., Alfabeta, Bandung Hal 622-661.

Sutrisno, Ida Aju Brahmasari, Hotman Panjaitan. 2016. The Influence of service Quality, and Customer Relationship Management (CRM) of patient Satisfaction, Brand Image, Trust, and patient Loyalty on Indonesian Army Level II Hospitals. International Journal of Business and management Invention. Volume 5 issue $5, p p$ : 30-44.

Thambirasa Sathiyaseelan,W.K.Athula C.Gnanapala. 2015. Service Quality and Patients Satisfaction on Ayurvedic Health Services. American Journal of Marketing Research. Vol. 1, No. 3, pp.158-166.

http://www. BambangSukmawijaya.wordpress.com 
Zahir Osman, Liana Mohamad, Ratna Khuzaimah Mohamad. 2015. An Empirical Study of Direct Relationship of Service Quality, Customer Satisfaction and bank image on Customer Loyalty in Malaysian Commercial Banking Industry. American Journal of Economics, 5(2): 168-176. 